\title{
Korelasi Antara Pola Asuh Orang Tua Dengan Sikap Religius
}

\author{
L.P.E.Septiani ${ }^{1}$, I K. Sudarma ${ }^{2}$, I K. Dibia ${ }^{3}$ \\ 1,3 Prodi Pendidikan Guru Sekolah Dasar, FIP, Universitas Pendidikan Ganesha \\ Singaraja, Indonesia \\ 2 Prodi Teknologi Pendidikan, Fakultas Ilmu Pendidikan, Universitas Pendidikan Ganesha \\ Singaraja, Indonesia \\ e-mail: ersaputu28@gmail.com
}

\begin{abstract}
Abstrak
Penelitian ini bertujuan untuk mengetahui hubungan antara pola asuh orang tua dengan sikap religius. Dalam penelitian ini, Terdapat tiga jenis pola asuh yang akan diteliti, yaitu pola asuh otoriter, demokratis, dan permisif. Populasi dalam penelitian ini adalah seluruh siswa kelas V SD dengan jumlah sampel sebanyak 132 siswa yang ditentukan menggunakan teknik proportional random sampling. Pengumpulan data pola asuh orang tua dan sikap religius siswa diperoleh melalui kuesioner. Teknik analisis data yang digunakan dalam penelitian ini menggunakan teknik analisis deskriptif. Uji hipotesis dalam penelitian ini adalah teknik analisis korelasi product moment. Hasil penelitian menunjukkan bahwa (1) terdapat hubungan positif antara pola asuh orang tua tipe demokratis dengan sikap religius Siswa Kelas V SD, yang dibuktikan dengan $r_{x y}$ hitung $(0.99)>r_{\text {tabel }}(0.143)$ yang berarti terdapat hubungan yang signifikan dengan kategori hubungan sangat kuat dengan kontribusi sebesar $98 \%$, (2) terdapat hubungan positif antara pola asuh orang tua tipe permisif dengan sikap religius, dibuktikan dengan $r_{x y}$ hitung $(0.58)>r_{\text {tabel }}(0.143)$ yang berarti terdapat hubungan yang signifikan dengan kategori hubungan cukup dengan kontribusi sebesar $34 \%$, dan (3) terdapat hubungan positif antara pola asuh orang tua tipe otoriter dengan sikap religius yang dibuktikan dengan $r_{x y}$ hitung $(0.79)>r_{\text {tabel }}(0.143)$ bermakna terdapat hubungan signifikan dengan kategori hubungan kuat dengan kontribusi sebesar $62 \%$. Jadi, pola asuh orang tua yang paling dominan adalah pola asuh orang tua tipe demokratis. Hasil penelitian memberikan simpulan yaitu terdapat hubungan antara pola asuh orang tua dengan sikap religius Siswa Kelas V SD. Saran dalam penelitian ini, hendaknya dalam kegiatan pembelajaran guru selalu memupuk sikap religius dengan cara tetap mengawali kegiatan dengan berdoa yang baik sehingga terjadi pembiasaan pada anak untuk menunjukaan sikap religius yang baik.
\end{abstract}

Kata kunci: pola asuh, sikap religius

\begin{abstract}
This purpose of research to find the relation between parenting with religious attitudes. This study, there are three types of parenting to be investigated, namely authoritarian, democratic, and permissive parenting. The populations in this study were all of $\mathrm{V}$ grade students in VI Widyastawa cluster Elementary School with a sample size of 132 students who were determined using a proportional random sampling technique. Data collection on parenting and religious attitudes of students was obtained through a questionnaire. Descriptive analysis techniques are used in this study as Data analysis techniques. The product-moment correlation analysis technique is used for testing the hypothesis in this study. The results showed (1) there was a positive relation between parenting style of democratic type parents with religious attitudes of Grade V Students of VI Widyastawa Cluster Elementary School, as evidenced by the correlation coefficient of $r_{x y}$ arithmetic $(0.99)>r_{\text {tabel }}(0.143)$, which means there was a relation which was significant with a very strong relationship category with a contribution of $98 \%$, (2) there was a positive relation between parenting permissive type of parents with religious attitude as evidenced by the correlation coefficient of $r_{x y}$ arithmetic (0.58)> $r_{\text {tabel }}(0.143)$ which means there is a significant relationship with a sufficient relation category with a contribution of $34 \%$, and (3) there is a positive relation between parenting authoritarian parents with a religious attitude as evidenced by the correlation coefficient of $r_{x y}$ arithmetic $(0.79)>r_{\text {tabel }}(0.143)$ which
\end{abstract}


means there is a significant relation with a strong relationship category with a contribution of $62 \%$. So, the most dominant parenting pattern is democratic parenting style. Based on the results of research and discussion, it can be concluded that there is a relation between parenting style and religious attitudes of V Grade. Suggestions in this study, teachers should always foster religious attitudes in learning activities by continuing to initiate activities by praying well so that it makes it habitual for children to show good religious attitudes.

Keywords: parenting, religious attitude

\section{Pendahuluan}

Pendidikan akan berkembang terus-menerus mengikuti tuntutan dan tantangan masa depan. Pendidikan berperan penting dalam mengembangkan kemampuan yang dimiliki untuk mendapatkan hasil yang baik. Pengembangan potensi dan karakter bertujuan untuk menjadikan pribadi beriman serta berbakti kepada Tuhan Yang Maha Esa. Membentuk karakter peserta didik perlu upaya-upaya pemerintah dalam memenuhi sesuatu yang dicanangkan. Upaya yang telah dilakukan untuk membentuk watak anak adalah melalui penanaman karakter. Penanaman karakter perlu dukungan penerapan dalam pembelajaran. Penanaman karakter yang harus dibangun dalam pembelajaran mencakup 18 karakter diantaranya adalah sikap religus.

Sikap religius dipandang sebagai wujud ketaatan dalam mengimplementasikan ajaran agama yang dianut, memiliki toleransi untuk menciptakan hidup harmonis (Yaumi, 2016). Pengimplemtasian nilai religius diperlukan pengarahan, bimbingan dan pendampingan. Sehingga, sikap religius pada anak itu dapat berkembang dengan baik berdasarkan hati nurani tanpa adanya tekanan dan paksaan. Sejalan dengan hal tersebut bahwa terdapat faktor-faktor yang memengaruhi pembentukan sikap religius pada anak salah satunya adalah keluarga.

Reiss (dalam Lestari, 2012) mendefinisikan keluarga sebagai suatu fungsi utama dalam sosialisasi pembentukan generasi baru yang didalamnya berbentuk kelompok kecil yang terstruktur dalam pertalian keluarga. Darmadi (2019) menyatakan bahwa keluarga sebagai tempat utama yang bepengaruh dominan. Dari beberapa pendapat tersebut, dapat dirangkum keluarga sebagai tempat utama yang terstruktur dan akan berpengaruh dominan bagi anak.

Wibowo (2012) yang menyatakan bahwa keluarga memiliki kontribusi besar dalam berhasilnya pembentukan karakter yang dapat dilihat dari aspek kuantitas waktu, lingkungan keluarga berkontribusi sekitar 70 persen di luar pendidikan formal. Melihat hal tersebut, bahwa keluarga bertanggung jawab besar terhadap berhasilnya pembentukan karkter anak yang didukung salah satunya oleh faktor yaitu parenting style.

Keberhasilan penanaman nilai karakter dalam keluarga disesuiakan pada pola asuh yang diterapkan. Pola asuh dipandang sebagai cara interaksi dalam membimbing dan mengarahkan perkembangan pengetahun, sikap, dan keterampilan anak. Dengan demikian, pola asuh yang tepat mendukung pengembangan sikap anak.

Berdasarkan observasi dan wawancara yang berlangsung pada tanggal 19-23 Oktober 2019 bersama guru-guru di lima SD gugus VI Kecamatan Gerokgak yang berlokasi di Desa Pemuteran, ditemukan data-data yang menunjukkan erat kaitannya dengan pola asuh orangtua dengan sikap religius siswa masih rendah. Rendahnya sikap religius disebabkan oleh salah satu faktor yaitu pola asuh orangtua.

Pola asuh orang tua yang diberikan, bepengaruh pada keberhasilan perwujudan sikap religius. Rendahnya sikap religius disebabkan oleh salah satu faktor yaitu pola asuh orang tua.. Fakta-fakta terkait sikap religius siswa rendah dapat dilihat dari ketidaktaatan siswa dalam beribadah dan kurangnya toleransi terhadap teman yang berbeda agama. Mengenai ketidaktaatan siswa dalam beribadah, siswa dalam bersembahyang sering bercanda, menggangu teman yang bersembahyang, dan menciptakan keributan saat bersembahyang. Sedangkan, kurangnya toleransi terhadap teman yang berbeda agama dapat dilihat dari kebiasaan mengejek teman yang berbeda agama, menjelekkan agama yang berbeda dengan yang dianut, dan menjauhi teman yang berbeda agama. 
Permasalahan tersebut harus segera dapat diatasi supaya tidak berkelajutan dan pembelajaran dapat berlangsung dengan efektif. Upaya yang tepat dalam memperbaiki masalah sikap religius masih rendah dengan mengkaji dan memperbaiki pola asuh orang tua supaya tidak menimbulkan masalah-masalah baru.

Berdasarkan masalah di atas, maka diangkat judul untuk mengkaji masalah tersebut dalam sebuah penelitian yang berjudul "Korelasi Antara Pola Asuh Orang Tua dengan Sikap Religius Siswa Kelas V pada SD Gugus VI Widyastawa Kecamatan Gerokgak Tahun Pelajaran 2019/2020.

\section{Metode}

Tempat dilaksanakan penelitian ini di SD Gugus VI Widyastawa Kecamatan Gerokgak meliputi lima sekolah dasar dengan jumlah populasi sebanyak 155 siswa. Hubungan antara pola asuh orang tua dengan sikap religius dapat dibuat pola hubungan antar variabel seperti Gambar 1.

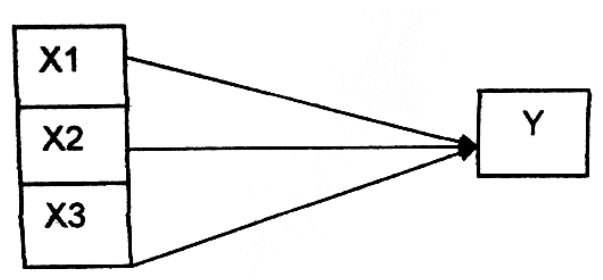

Gambar 1. Pola Hubungan Variabel Penelitian

Keterangan:

(Sumber: Sugiyono, 2006:255)

$\mathrm{X} 1 \quad$ : tipe demokratis

X2 : tipe permisif

X3 : tipe otoriter

$\mathrm{Y} \quad$ : sikap religius

$\longrightarrow$ : hubungan

Penentuan sampel diperoleh melalui teknik proportional random sampling. Berdasarkan perhitungan tersebut, sampel diperoleh sebanyak 132 siswa. Pola asuh orang tua sebagai variabel bebas sedangkan sikap religius sebagai variabel terikat.

Kuesioner digunakan sebagai instrumen pengumpulan data dalam memperoleh data pola asuh orang tua dan sikap religius. Hasil validitas yang diperoleh dibandingkan dengan kriteria validitas isi yang menunjukkan bahwa 33 butir pernyataan instumen pola asuh orang tua dan 35 butir pernyataan instrumen sikap religius telah lulus uji pakar/judges dengan tingkat validitas isi sangat tinggi, yaitu 1,00. Hasil validitas empirik instrumen pola asuh orang tua dinyatakan valid berjumlah 30 pernyataan atau $90.9 \%$. Instrumen sikap religius dapat dinyatakan valid sebanyak 31 butir pernyataan atau $88.6 \%$. Pengujian relibilitas menggunakan rumus Alpha Cronbach, didapatkan reliabilitas angket pola asuh orang tua sebesar 0,60 apabila dibandingkan dengan koefisien reliabilitas memiliki kategori reliabilitas tinggi. Sedangkan, hasil uji reliabilitas angket sikap religius didapatkan sebesar 0,63 apabila dibandingkan dengan koefisien reliabilitas memiliki kategori reliabilitas tinggi.

Penelitian ini menggunkan teknik analisis statistik destriptif. Uji prasyarat meliputi uji normalitas, uji linieritas serta uji hipotesis. Uji hipotesis dilakukan dengan korelasi product moment. 


\section{Hasil dan Pembahasan}

Hasil penelitian ini memuat data mengenai pola asuh orang tua dan data sikap religius yang diperoleh melalui kuesioner. Tabel hasil analisis deskriptif dapat disajikan sebagai berikut.

Tabel 1 Hasil Analisis Deskriptif

\begin{tabular}{ccccc}
\hline Variabel & $\begin{array}{c}\text { Tipe } \\
\text { Demokratis }\end{array}$ & Tipe Permisif & Tipe Otoriter & Sikap Religius \\
\hline $\mathrm{N}$ & 132 & 132 & 132 & \\
Mean & 33.8 & 35.15 & 32.15 & 97.2 \\
Standar & 11.55 & 11.25 & 11.4 & 21.6 \\
Deviasi & & & & \\
Minimum & 10 & 12 & 10 & 61 \\
Maksimum & 50 & 50 & 50 & 138 \\
\hline
\end{tabular}

Berdasarkan hasil perhitungan analisis statistik deskriptif, diperoleh rerata pola asuh tipe demokratis sebesar 33.8 menunjukkan kategori sedang. Sedangkan, rerata pola asuh tipe permisif diperoleh sebesar 35.15 yang berada pada kategori sedang, dan rerata pola asuh orang tua tipe otoriter diperoleh sebesar 32.15 yang berada pada kategori sedang, serta rerata sikap religius diperoleh sebesar 97.2 yang berada pada kategori sedang.

Sebelum melakukan pengujian hipotesis, data penelitian harus berdistribusi normal dan linier. Di bawah ini akan disajikan sebagai berikut.

\begin{tabular}{cccccc}
\multicolumn{5}{c}{ Tabel 2 Hasil Uji Normalitas } \\
\hline \multicolumn{2}{c}{ Variabel } & & ${ }^{2}$ hitung & ${ }^{2}$ tabel & Status \\
\hline Pola Asuh Orang & Tua Tipe & 24.24 & 158.71 & Normal \\
Demokratis & & & & \\
Pola Asuh Orang Tua Tipe Permisif & 23.11 & 158.71 & Normal \\
Pola Asuh Orang Tua Tipe Otoriter & 23.85 & 158.71 & Normal \\
Sikap Religius & 19.7 & 158.71 & Normal \\
\hline
\end{tabular}

Hasil perhitungan normalitas dengan menggunakan teknik Chi-Square, kriteria yang berlaku apabila ${ }^{2}$ hitung $>{ }^{2}$ tabel maka data tersebut berdistribudi normal. Hasil perhitungan menunjukkan bahwa pola asuh orang tua tipe demokratis, pola asuh orang tua tipe permisif, pola asuh orang tua tipe otoriter, dan sikap religius tergolong normal.

Setelah data berdistribusi normal, dilanjutkan uji linieritas berbantuan SPSS 22. Hasil uji linieritas disajikan pada Tabel 3 di bawah ini.

Tabel 3 Hasil Uji Linieritas

\begin{tabular}{lccc}
\hline \multicolumn{1}{c}{ Variabel } & $\begin{array}{c}\text { Sig. Deviation } \\
\text { From Linearity }\end{array}$ & $\begin{array}{c}\text { Taraf } \\
\text { Signifikansi }\end{array}$ & Status \\
\hline Pola Asuh Orang Tua Tipe Demokratis & 0.723 & 0.05 & Linier \\
Pola Asuh Tipe Permisif & 0.953 & 0.05 & Linier \\
Pola Asuh OrangTua Tipe Otoriter & 0.170 & 0.05 & Linier \\
\hline
\end{tabular}

Uji linieritas data dianalisis dengan menggunakan teknik statistik Test of Linearity. Hubungan linieritas ditunjukkan pada nilai signifikansi deviation from linearity. Nilai signifikansi yang diperoleh lebih besar dari 0.05, hubungan dikatakan linier. Berdasarkan Tabsel 3, variabel $X_{1}, X_{2}$, dan $X_{3}>0.5$, sehingga variabel dalam penelitian ini linier.

Setelah data linier, selanjutnya dilakukan pengujian hipotesis. Pengujian hipotesis ditentukan menggunakan teknik korelasi product moment. Pada Tabel 4 disajikan hasil uji hipotesis sebagai berikut. 


\begin{tabular}{lcc}
\hline \multicolumn{1}{c}{ Variabel } & $\mathbf{r}_{\mathbf{x y}}$ hitung & $\mathbf{r}$ tabel \\
\hline Pola Asuh Orang Tua TipeDemokratis & 0.99 & 0.143 \\
PolaAsuh Orang Tua Tipe Permisif & 0.58 & 0.143 \\
Pola Asuh Orang Tua Tipe Otoriter & 0.79 & 0.143 \\
\hline
\end{tabular}

Berdasarkan tabel 4, dapat dideskripsikan hubungan pola asuh orang tua dengan sikap religius sebagai berikut, pola asuh orang tua tipe demokratis sebesar 0.99 , pola asuh orang tua tipe permisif sebesar 0.58 dan pola asuh orang tua otoriter sebesar 0.79 .

Pengujian hipotesis pertama, yaitu pola asuh tipe demokratis $\left(X_{1}\right)$ terhadap sikap religius $(\mathrm{Y})$, didapatkan nilai $r_{\mathrm{xy}}$ sebesar 0.99 dan sumbangan efektif sebesar $98 \%$. Berdasarkan hasil perhitungan persamaan garis regresi, dapat ditentukan persamaan berikut. $\widehat{\mathrm{Y}}=40.1+1.77 \mathrm{X}$. Persamaan tersebut menunjukkan $a=40.1$ bermaknai pola asuh orang tua tipe demokratis $(\mathrm{X})$. Sedangkan, $\mathrm{b}=$ angka koefisien regresi yang bernilai 1.77 , angka koefisien bermakna bahwa setiap pola asuh orang tua tipedemokratis bertambah sebesar $1 \%$, maka sikap religius siswa kelas V SD Gugus VI Widyastawa Kecamatan Gerokgak Tahun Pelajaran 2019/2020 akan meningkat sebesar 1.77. Berdasarkan hal tersebut, terdapat korelasi positif yang signifikan antara pola asuh orangtua tipe demokratis dengan sikap religius siswa kelas V SD Gugus VI Widyastawa Kecamatan Gerokgak.

Pola asuh tipe demokratis memberikan sumbangan paling besar dalam hasil penelitian. Hal tersebut menun jukkan, pola asuh tipe demokratis paling dominan terhadap siswa kelas $\mathrm{V}$ SD Gugus VI Widyastawa Kecamatan Gerokgak. Besarnya kontribusi polaasuh orang tua tipe demokratis disebabkan karena dalam penerapan pola asuh tipe demokratis, anak selalu diberikan bimbingan serta pengarahan terkait perilaku yang diperbuat anak, dan pemberian kebebasan untuk anak melakukan apapun dengan batasan-batasan tertentu. Sehingga, anak merasa dihargai untuk mengembangkan perilaku yang baik.

Pengarahan dan bimbingan tersebut salah satunya dalam pembentukan sikap religius anak. Dalam pembentukan sikap religius anak dibimbing dan diarahkan untuk berdoa dengan sikap yang benar, toleransi terhadap orang yang berbeda agama untuk menciptakan hidup rukun dan harmonis. Orang tua yang selalu memberikan pengarahan tentunya akan memberikan dampak pada kebiasaan anak untuk melakukan hal tersebut. Sehingga, menjadikan anak tersebut terarah ke perkembangan yang positif salah satunya sikap religius.

Pola asuh demokratis lebih menekankan aturan terkait dengan pemahaman tidak dengan tekanan dan paksaan. Dengan demikian, orang tua berkesempatan untuk memberikan pengarahan dan bimbingan untuk mewujudkan prilaku dan pribadi yang baik. Terkait dengan hasil penelitian, pengembangan sikap religius, mandiri, dan tanggungjawab lebih didukung oleh orang tua yang menerapkan pola asuh demokratis sehingga pola asuh ini lebih tepat dalam membentuk karakter anak (Wibowo, 2012).

Untuk mendidik anak supaya memiliki sikap religius dengan menyenangkan tanpa ada perasaan tertekan, keluarga harus mendidik anak dengan cara menuntun, mengarahkan sekaligus mendampingi anak dalam melaksanakan perwujudan sikap religius. Sehingga sikap religius pada anak itu dapat berkembang dengan baik berdasarkan hati nurani tanpa adanya tekanan dan paksaan. Senada dengan hasil penelitian yang dilakukan oleh Susilawati (2018) bahwa terdapat hubungan positif yang signifikan antara religiusitas dan pola asuh demokratis dengan perkembangan moral dengam loefisien $r x 12 y=0.436$ dengan $p=0.000$, dan nilai kontribusi sebesar $19.0 \%$.

Pengujian hipotesis yang kedua yaitu pola asuh tipe permisif $\left(X_{2}\right)$ terhadap sikap religius (Y), didapatkan nilai $r_{x y}$ sebesar 0.58 dan diperoleh kontribusi sebesar $34 \%$. Berdasarkan hasil perhitungan persamaan garis regresi, dapat ditentukan persamaan garis regresi sebagai berikut. $\widehat{\mathrm{Y}}=57.8+(1.09) \mathrm{X}$. Persamaan garis regresi tersebut menunjukkan $a=57.8$ yang berarti pola asuh tipe permisif $(X)$. Sedangkan, $b=$ angka koefisien regresi yang bernilai 1.09, angka koefisien regresi bermakna bahwa setiap penambahan $1 \%$ pola asuh tipe permisif, maka sikap religius siswa kelas V SD Gugus VI Widyastawa Kecamatan Gerokgak Tahun 
Pelajaran 2019/2020 akan mengalami peningkatan sebesar 1.09. Koefisien regresi menunjukkan nilai (+). Berdasarkan hal tersebut, pola asuh tipe permisif berkorelasi positif terhadap sikap religius siswa kelas V SD Gugus VI Widyastawa Kecamatan Gerokgak Tahun Pelajaran 2019/2020.

Pola asuh tipe permisif memberikan sumbangan efektif paling kecil dibandingkan dengan pola asuh orangtua tipe demokratis dan pola asuh tipe otoriter. Hal tersebut terjadi, karena orang tua yang menerapkan polaasuh tipe permisif lebih menekankan pada pemberian kebebasan dalam berbuat apapun. Pemberian kebebasan tersebut dapat berpengaruh pada karakter anak salah satunya pada sikap religius.

Sikap religius perlu ditumbuhkan pada anak sejak dini. Sikap religius dipandang sebagai ketaatan sesorang dalam menjalankan ajaran agamanya untuk mewujudkan hubungan yang harmonis dalm kehidupan sehari-hari. sikap religius akan menggambarkan nilai-nilai religiusitas yang diperoleh melalui pengarahan dan bimbingan dalam kehidupan sehari-hari melalui pola asuh orang tua.

Penerapan pola asuh permisif lebih dominan pada anak, orang tua memperbolehkan anak dalam melakukan apapun sesuai dengan keinginannya. Mereka yang mampu memanfaatkan dengan baik kebebasan dalam pola asuh permisif pemberian orang tua, tentu akan menjadi pribadi dewasa dan bertanggung jawab. Dariyo (2016) menyatakan bahwa anak yang diberikan kebebasan dapat menumbuhkan kembangkan sikap positif yaitu sikap religius dan nasionalisme.

Berdasarkan hal tersebut, bahwa semakin kuat penerapan pola asuh permisif maka semakin terjadi peningkatan pada sikap religius anak. Hasil penelitian ini senada dengan hasil penelitian yang dilakukan oleh Asri yang menyatakan bahwa terdapat hubungan positif antara pola asuh otoriter, demokratis, dan permisif dengan perkembangan nilai moral agama.

Pengujian hipotesis yang ketiga yaitu pola asuh tipe otoriter $\left(X_{3}\right)$ terhadap sikap religius $(\mathrm{Y})$, diperoleh nilai $r_{x y}$ sebesar 0.79 dengan sumbanganefektif sebesar $62 \%$. Berdasarkan hasil perhitungan persamaan garis regresi, dapat ditentukan persamaan sebagai berikut. $\widehat{Y}=$ $47.7+1.42 \mathrm{X}$. Persamaan garis regresi tersebut menunjukkan $a=47.7$ yang bermakna pola asuh tipe otoriter $(X)$. Sedangkan, $b=$ angka koefisien regresi yang bernilai 1.42 , angka koefisien regresi ini bermakna setiap peningkatan $1 \%$ pola asuh orang tua tipe otoriter, maka sikap religius siswa kelas V SD Gugus VI Widyastawa Kecamatan Gerokgak Tahun Pelajaran 2019/2020 akan meningkat sebesar 1.42. Koefisien regresi menunjukkan nilai (+). Berdasarkan hal tersebut, bahwa pola asuh orang tua tipe otoriter memberikan pengaruh positif terhadap sikap religius siswa kelas V SD Gugus VI Widyastawa Kecamatan Gerokgak Tahun Pelajaran 2019/2020.

Pola asuh tipe otoriter memberikansumbangan sebesar $62 \%$ terhadap sikap religius. Hal tersebut disebabkan oleh pemberian pengawasan ketat terhadap perilaku anak, orang tua sering menghukum jika anak tidak patuh terhadap perintah dan keinginannya, dan orang tua memiliki kekuasaan yang dominan dibandingkan anak. Hal tersebut senada dengan pendapat Wibowo (2012) karakteristik pola asuh otoriter orang tua memiliki kekuasan amat tinggi, pengwasan terhadap tingkah laku anak sangat ketat; dan pemberian hukuman apabila anak tidak tunduk pada perintahnya.

Berdasarkan hal tersebut, dalam penerapan pola asuh orang tua tipe otoriter orang tua melakukan control/pengawasan pada perilaku anak dengan sangat ketat salah satunya pada sikap religius. Impelementasi pola asuh otoriter dalam membentuk sikap religius orangtua harus mampu menjadi contoh teladan bagi anaknya dan akan memberikan hukuman jika anak tidak mematuhi perintahnya. Hal tersebut didukung oleh pendapat Kurniawan (2013) menyatakan bahwa sikap religius akan dapat berkembang pada anak apabila orang tua mampu menjadi contoh teladan, sehingga orang tua akan dituruti perintahnya. Sejalan dengan hal tersebut, bahwa erat hubungannya antara pola asuh orang tua tipe otoriter dengan pembentukan sikap religius.

Orang tua menerapkan pola asuh otoriter dalam pembentukan sikap religius akan memberikan pengawasan yang sangat ketat, sehingga anak memang benar-benar melakukan sikap religius seperti berdoa tepat waktu, berdoa dengan sikap yang benar, dan selalu menghargai orang yang berbeda maupun seagama. Tujuannya, supaya anak disiplin dan 
bersungguh-sungguh dalam menjalankan ajaran agama yang dianutnya yang berkaitan dengan wujud bakti kepada Tuhan dan sesama. Hasil penelitian ini senada dengan penelitian yang dilakukan oleh Putri dan Noviekayati (2015) menunjukkan pengasuhan cenderung otoriter yang diterapkan dengan tujuan agar anak belajar agama dengan sungguh-sungguh, mengingat ajaran agama dan nilai yang ada didalamnya sangat luhur yang bersumber dari Tuhan, sehingga dibutuhkan kedisiplinan dalam mempelajari, menghayati, dan menerapkannya. Berdasarkan hal tersebut, semakin sering penerapan pola asuh tipe otoriter pada anak, sikap religius semakin meningkat.

\section{Simpulan}

Berdasarkan hasil penelitian, dapat ditunjukkan bahwa terdapat hubungan positif yang signifikan antara pola asuh orang tua dengan sikap religius yang dibuktikan oleh pengujian hipotes I diperoleh $r_{x y}$ hitung sebesar $(0.990$ > rtabel $(0.143)$ yang berarti terdapat hubungan sangat kuat antara pola asuh orang tua tipe demokratis dengan sikap religius Siswa Kelas $\mathrm{V}$ SD Gugus VI Widyastawa Kecamatan Gerokgak. Pengujian hipotesis II diperoleh $r_{x y}$ sebesar $(0.58)>r$ tabel (0.143) yang berarti terdapat hubungan cukup antara pola asuh tipe permisif dengan sikap religius Siswa Kelas V SD Gugus VI Widyastawa Kecamatan Gerokgak. Selanjutnya, pengujian hipotesis III diperoleh $r_{x y}$ sebesar $(0.79)>r$ tabel $(0.143)$ yang berarti terdapat hubungan kuat antara pola asuh orang tua tipe otoriter dengan sikap religius Siswa Kelas V SD Gugus VI Widyastawa Kecamatan Gerokgak. Berdasarkan hal tersebut, dalam penelitian ini yang memiliki tingkat hubungan yang sangat kuat dengan sikap religius adalah pola asuh orang tua tipe demokratis.

\section{Daftar Pustaka}

Agung, A.A.G. 2014. Statistika Dasar Untuk Pendidikan. Yogyakarta: Deepublish.

Anggraini, dkk., (2017). "Hubungan Pola Asuh Orang Tua dengan Kepribadian Siswa SMA di Kota Bengkulu". Jurnal Ilmiah Bimbingan dan Konseling. Vol. 1, No.1 (hlm. 13). Tersedia pada: $\quad$ https://ejournal.unib.ac.id/index.php/j consilia/article/viewFile/3978/2212. Diakses, 19 Oktober 2019.

Asri, Sri. 2018. "Hubungan Pola Asuh Terhadap Perkembangan Anak Usia Dini”. Jurnal Ilmiah Sekolah Dasar. Vol. 2, No. 1 (hlm. 1-9). Tersedia pada: https://ejournal.undiksha.ac.id/index.php/JISD/article/view/13793. Diakses, 23 Januari 2020.

Dantes, N. 2012. Metode Penelitian. Yogyakarta: Andi.

Darmadi, Hamid. 2019. Pengantar Pendidikan Era Globalisasi. Jakarta: An1mage Team.

Fellasari dan Lestari. 2016."Hubungan Antara Pola Asuh Orang Tua dengan Kematangan Emosi Remaja". Jurnal Psikologi. Vol. 12, No. 2 (hlm. 85). Tersedia pada: http://ejournal.uin-suska.ac.id/index.php/psikologi/article/view/3234. Diakses, 20 Oktober 2019.

Gading, K., dkk. 2018. "Buku Ajar Belajar dan Pembelajaran". Singaraja: Undiksha Press.

Karnangsyah. (2017). "Hubungan Pola Asuh Orang tua dengan Hasil Belajar Siswa dan Implikasinya Terhadap Pelayanan Bimbingan dan Konseling". Jurnal EDUCATIO. Vol. 3, No.1 (hlm.1-9). Tersedia pada: http://www.jurnal.iicet.org/index.php/jedu/article/view/65/56. Diakses, 23 Januari 2020.

Koyan, W. 2012. Asesmen Dalam Pendidikan. Singaraja: Universitas Pendidikan Ganesha Press.

Kurniawan, Syamsul. (2013). "Pendidikan Karakter (Konsepsi \& Implementasinya Secara Terpadu di Lingkungan Keluarga, Sekolah, Perguruan Tinggi, \& Masyarakat". Yogyakarta: AR-RUZZ Media

Netra, B. I. 1974. Statistik Inferensial. Surabaya: Usaha Nasional.

Rasyid, Harun, dkk.2007. Hasil Belajar. Bandung: CV Wacana Prima.. 
Risthantri dan Sudrajat. (2015). "Hubungan Antara Pola Asuh Orang Tua dan Ketaatan Beribadah dengan Perilaku Sopan Santun Peserta Didik”. Jurnal Pendidikan IPS. Vol. 2, No.2 (hlm.192). Tersedia pada: https://journal.uny.ac.id/index.php/hsjpi/article/view/7670. Diakses, 23 Januari 2020.

Sari dan Renggani. 2018. "Hubungan Pola Asuh Orangtua Dan Teman Sebaya Terhadap Kedisiplinan Belajar Siswa Kelas III SD". Joyful Jurnal Learning. Vol. 7, No. 4 (hlm. 58). Tersedia pada: file:///C:/Users/ACER/Downloads/23984-Article\%20Text-69375-1-1020190501(1).pdf. Diakses, 18 Oktober 2019.

Setyawan, Budi. 2017. Pedoman Metodologi Penelitian (Statistika Praktis). Jakarta: Zifatama Jawara.

Sugiyono. 2006. Metode Penelitian Kuantitatif dan $R$ \& D. Bandung: Alfabeta.

Sunarty, Kustiah. 2016. "Hubungan Pola Asuh Orang Tua dan Kemandiriaan Anak". Jurnal Of Educational Science and Technology. Vol. 2, No. 3 (hlm. 152-160). Tersedia pada: https://ojs.unm.ac.id/JEST/article/view/3214/1826. Diakses, 23 Januari 2020.

Susetyo. 2012. Statistika Untuk Analisis Data Penelitian. Bandung: PT Refika Aditama.

Tridhonanto, Al. 2014. Mengembangkan Pola Asuh Demokrtis. Jakarta: PT Elex Media Komputindo.

Wibowo, Agus. 2012. Pendidikan Karakter: Strategi Membangun Karakter Bangsa Berkpribadian. Yogyakarta: Pustaka Pelajar.

Yauarti, Eka. 2018. "Pengaruh Sikap Religiusitas terhadap Perilaku Hidup Bersih dan Sehat Masyarakat Kabupaten Rejang Lebong". Jurnal Kajian Keislaman dan Kemasyarakatan. Vol. 3 , No.1 (hlm.12-15). Tersedia pada: http://journal.staincurup.ac.id/index.php/JF/article/view/387. Diakses, 18 Oktober 2019.

Yaumi, Muhammad. 2014. Pendidikan Karakter: Landasan, Pilar \& Implementasi. Jakarta: Prenadamedia Group.

Zubaedi. 2011. Desain Pendidikan Karakter Konsepsi dan Aplikasinya dalam Lembaga Pendidikan. Jakarta: Kencana. 